\title{
Delivery of a fetus with undiagnosed sacro coccygeal teratoma
}

\author{
Hemalatha Radhakrishna Kabadi, Chandana Murthy SR*, Mnajunath B. Shivanna
}

Department of Obstetrics \& Gynaecology, Karnataka Institute of Medical Science, Hubli, Karnataka, India

Received: 27 February 2015

Accepted: 19 April 2015

\section{*Correspondence:}

Dr. Chandana Murthy SR,

E-mail: chandana.ramchandra@gmail.com

Copyright: ( $)$ the author(s), publisher and licensee Medip Academy. This is an open-access article distributed under the terms of the Creative Commons Attribution Non-Commercial License, which permits unrestricted non-commercial use, distribution, and reproduction in any medium, provided the original work is properly cited.

\section{ABSTRACT}

Sacrococcygeal teratoma is the most common tumour of the fetus and neonate with an incidence of 1 in 40000 births. Here we describe the management of an undiagnosed sacrococcygeal teratoma, which is rare in this era.

Keywords: Sacrococcygeal teratoma, Delivery

\section{INTRODUCTION}

Sacrococcygeal teratoma is the most common tumour of the fetus and neonate with an incidence of 1 in 40000 births. ${ }^{1}$ Their embryological origin is from the pluripotent cells in Hensen's node of the primitive streak and contain components arising from the 3 layers: endoderm, mesoderm and ectoderm. Their midline distribution can be explained by the arrest or aberrant migrationof primordial germ cells. ${ }^{2}$ The commonest site for extragonadal teratomas is the sacral region, followed by the anterior mediastinum, pineal, retroperitoneum, neck, stomach, and vagina. ${ }^{3}$

\section{CASE REPORT}

25 year old female presented to KIMS Hubli labour room with history of G3P2L1 with term gestation with severe polyhydramnios in active labour. She was an unbooked case with no antenatal records. On examination-vitals stable, abdomen overdistended, uterus acting, cephalic lower pole with FHR-136-140/minute. PV examinationcervix $7-8 \mathrm{~cm}$ dilated, well effaced with vertex at 0 station and pelvis adequate. ARM done - 2.5 to 3 litres of clear liquor drained. She progressed well. Baby delivered till thorax. Further delivery of the baby was difficult. Examiner inserted her hand along the back of the baby - a firm to cystic mass was felt. A provisional diagnosis of obstructed labour due to tumour on the dorsum of the back was made. Emergency USG revealed a heterogenous mixed echogenic mass on the sacral part of the fetus of $10 \times 12 \times 12 \mathrm{~cm}$. Abdomen was still 34 weeks size. Patient was shifted to emergency laparotomy after her consent. Intraoperative findings - uterus overdistended, lower uterine horizontal incision takenhuge firm to cystic mass (mainly solid component) measuring $12 \times 15 \times 15 \mathrm{~cm}$ on the fetal back noted. Attempts to reposition the baby thorax and head into the vagina and delivery through uterine incision were unsuccessful. Tumour did not shrink on aspiration. Hence the tumour was excised and removed through uterine incision and the baby was delivered vaginally. Uterus closed in two layers and abdomen closed in layers. Postoperative period was uneventful (Figure 1, 2 and 3).

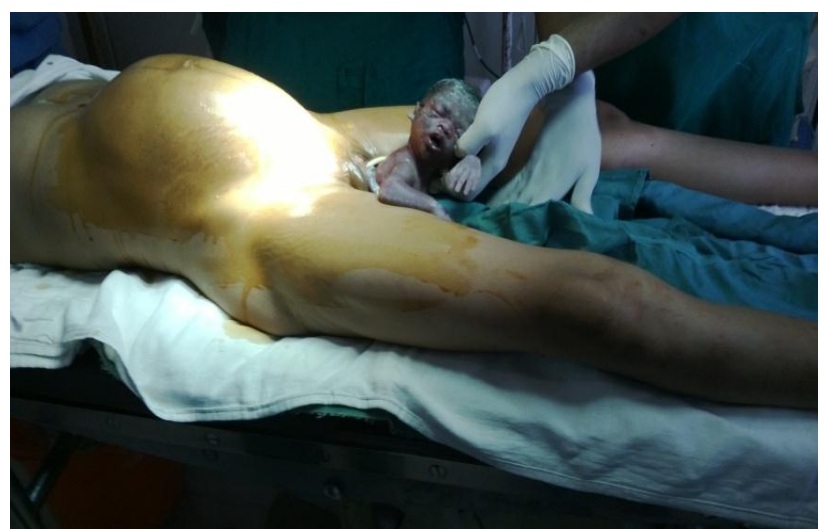

Figure 1: Baby delivered till thorax. 


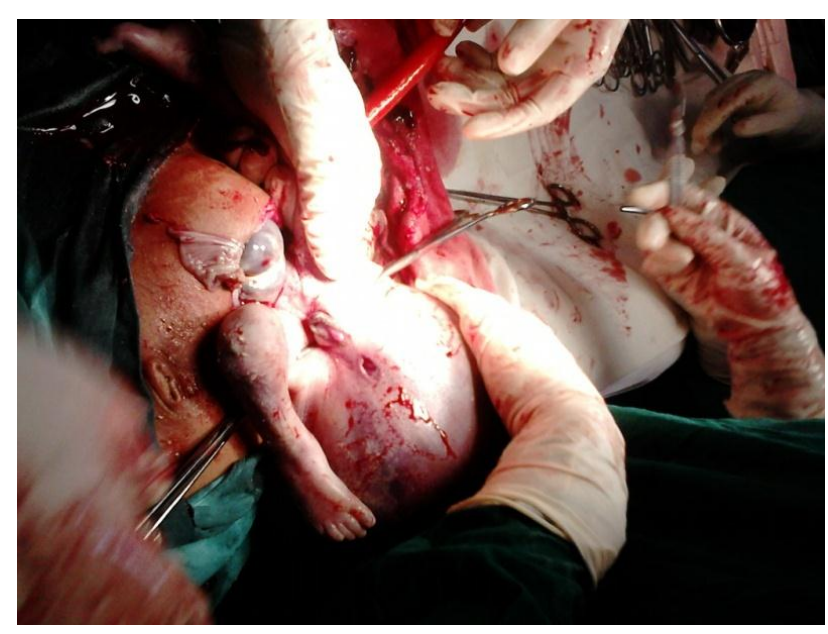

Figure 2: Resection of the sarococcygeal teratoma.

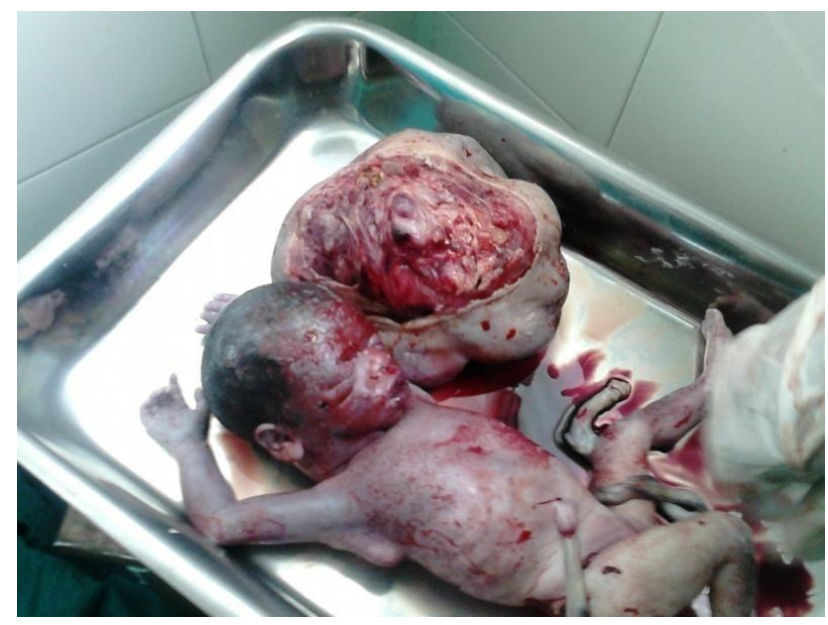

Figure 3: Resected sacrococcygeal teratoma.

\section{DISCUSSION}

Fetal death may be caused by high-output cardiac failure from arteriovenous shunting through the tumor, ${ }^{4,5}$ rupture of tumour during delivery with a massive hemorrhage. ${ }^{6}$
There is evidence that antenatal resection earlier in the course of the disease is more likely to have a successful outcome. $^{7}$

\section{Funding: No funding sources \\ Conflict of interest: None declared \\ Ethical approval: Not required}

\section{REFERENCES}

1. Dillard BM, Mayer JH, McAlister WH, McGavrin M, Strominger DB. Sacrococcygeal teratoma in children. J Pediatr Surg. 1970;5:53-9.

2. Teilum G. Classification of endodermal sinus tumour (mesoblastoma vitellinum) and so called bembryonal carcinomaQ of the ovary. Acta Pathol Microbiol Scand. 1965;64:407-29.

3. Flake AW, Harrison MR, Adzick NS, Laberge JM, Warsof SL. Fetal sacrococcygeal teratoma. J Pediatr Surg. 1986;21:563-6.

4. Schmidt KG, Silverman NH, Harrison MR, Callen PW. High-output cardiac failure in fetuses with large sacrococcygeal teratoma: diagnosis by echocardiography and Doppler ultrasound. J Pediatr. 1989;114:1023-8.

5. Brace V, Grant SR, Brackley KJ, Kilby MD, Whittle MJ. Prenatal diagnosis and outcome in sacrococcygeal teratomas: a review of cases between 1992 and 1998. Prenat Diagn. 2000;20:51-5.

6. Holterman AX, Filiatrault D, Lallier M, Youssef S. The natural history of sacrococcygeal teratomas diagnosed through routine obstetric sonogram: a single institution experience. J Pediatr Surg. 1998;33:899-903.

7. Adzick NS, Crombleholme TM, Morgan MA, Quinn TM. A rapidly growing fetal teratoma. Lancet. 1997;349:538.

DOI: $10.18203 / 2320-1770$. ijrcog20150106

Cite this article as: Kabadi HR, Chandana Murthy SR, Shivanna MB. Delivery of a fetus with undiagnosed sacro coccygeal teratoma. Int J Reprod Contracept Obstet Gynecol 2015;4:846-7. 